\title{
Lineage specific role of Ship1 in development of allergic airway inflammation
}

\author{
Matthew J Gold*, Michael R Hughes, Frann Antignano, Colby Zaph, Kelly M McNagny \\ From Canadian Society of Allergy and Clinical Immunology Annual Scientific Meeting 2014 \\ Ottawa, ON, Canada. 23-26 October 2014
}

\section{Background}

The PI3K pathway is a potent mediator of several functions associated with asthma pathogenesis, including supporting leukocyte survival, activation, migration and cytokine release. Proper negative regulation of this pathway is integral in order to restrict overactive immune responses. Negative regulation of PI3K is predominantly controlled by the lipid phosphatases PTEN and SHIP-1. Inpp5d (Ship1) deficient mice develop spontaneous airway inflammation and have enhanced sensitivity to allergen induced airway inflammation. We hypothesized that deleting Ship1 expression specifically in lineages known to be crucial for adaptive Th2 responses would uncover more subtle effects that could either positively or negatively regulate disease severity in a mouse model of allergic airway inflammation (AAI).

\section{Methods}

Ship1 expression was deleted in B cell, $\mathrm{T}$ cell and dendritic cell (DC) lineages and the resulting Ship1 $1^{\Delta \mathrm{B} \text { cell }}$, Ship1 ${ }^{\Delta \mathrm{T}}$ cell and Ship1 ${ }^{\Delta \mathrm{DC}}$ mice were exposed to house dust mite (HDM) antigen over an 18-day period. Infiltrating leukocytes in the bronchoalveolar lavage (BAL) and lung, serum antibody levels and Th1 and Th2 cytokine responses were quantified to assess disease severity.

\section{Results}

Deletion of Ship1 in either the B cell, T cell or DC lineages did not result in spontaneous airway inflammation, and loss of Ship1 in the B cell linage did not affect HDM-induced AAI. Surprisingly, loss of Ship1 in either of the T cell or DC lineages protected from development of AAI by skewing the HDM-induced immune response

\footnotetext{
* Correspondence: mgold@brc.ubc.ca

The Biomedical Research Centre, University of British Columbia, Vancouver,
} British Columbia, V6T 1Z3, Canada

(c) 2014 Gold et al; licensee BioMed Central Ltd. This is an Open Access article distributed under the terms of the Creative Commons Attribution License (http://creativecommons.org/licenses/by/4.0), which permits unrestricted use, distribution, and reproduction in any medium, provided the original work is properly cited. The Creative Commons Public Domain Dedication waiver (http:// creativecommons.org/publicdomain/zero/1.0/) applies to the data made available in this article, unless otherwise stated. to a Th1 phenotype instead of the characteristic Th2 phenotype associated with allergic asthma.

\section{Conclusions}

While loss of Ship1 expression throughout the hematopoietic populations leads to spontaneous lung inflammation, selective deletion of Ship1 in T cells and DCs impairs the formation of an adaptive Th2 response and protects from the development of AAI.

\section{Acknowledgments}

This work was supported by AllerGen Inc. and the Canadian Institutes of Health Research (CIHR).

Published: 18 December 2014

doi:10.1186/1710-1492-10-S2-A56

Cite this article as: Gold et al:: Lineage specific role of Ship1 in

development of allergic airway inflammation. Allergy, Asthma and Clinical Immunology 2014 10(Suppl 2):A56.
Submit your next manuscript to BioMed Central and take full advantage of:

- Convenient online submission

- Thorough peer review

- No space constraints or color figure charges

- Immediate publication on acceptance

- Inclusion in PubMed, CAS, Scopus and Google Scholar

- Research which is freely available for redistribution Submit your manuscript at
www.biomedcentral.com/submit C BioMed Central 